\title{
A fungal proliferation near the probable Oligocene/Miocene boundary, Nukhul Formation, Gulf of Suez, Egypt
}

\author{
HAYTHAM EL ATFY ${ }^{1,2 *}$, RAINER BROCKE ${ }^{1} \&$ DIETER UHL ${ }^{1,3}$ \\ ${ }^{1}$ Senckenberg Research Institute and Natural History Museum, 60325 Frankfurt am Main, Germany \\ ${ }^{2}$ Geology Department, Faculty of Science, Mansoura University, 35516 Mansoura, Egypt \\ ${ }^{3}$ Senckenberg Centre for Human Evolution and Palaeoenvironment, Tübingen University, 72076 Tübingen, Germany \\ *Corresponding author*(e-mail: helatfy@senckenberg.de)
}

\begin{abstract}
Moderately to well-preserved palynomorph assemblages were recorded from thirty samples of the Nukhul Formation (GH 404-2A Well), southern Gulf of Suez, Egypt. The taxa are dominated by highly diverse fungi, freshwater algae (e.g. Botryococcus, Pediastrum) beside a sparse record of spores and pollen. Marine palynomorphs, such as dinoflagellate cysts (dinocysts), are very rare. The stratigraphy and age of the Nukhul Formation is highly debated due to lack of diagnostic fossils (e.g. foraminifera, nannoplankton). It has been referred mostly to the Early Miocene; however, some recent publications interpret it as being of latest Oligocene-Early Miocene age. A prominent fungal proliferation composed of diverse and moderately well-preserved fungal spores, fungal fragments, fructifications and hyphae is recorded. This fungi-rich interval occurs mainly from 11370 to $11430 \mathrm{ft}$ in the GH 404-2A Well. Such an observation has not been noted previously within the Nukhul Formation or its stratigraphic equivalents in Egypt. This putative 'eco-event' is probably associated with the well-known eustatic sea-level fall in the latest Chattian to early Aquitanian or at the Oligocene/Miocene boundary (OMB). It also seems possible that it may represent a more local event related to the rifting of the Gulf of Suez during this period. The high diversity of fossil fungi is interpreted herein as an indication of an episodic prevalence of humid climate at the end of a regressive phase, as also indicated by a lithological change near the top of the Shoab Ali Member of the Nukhul Formation. In addition, the co-occurrence of freshwater algae, mainly Botryococcus and Pediastrum, together with some aquatic fungal genera, such as Involutisporonites, Paragrantisporites, Quilonia, Striadiporites and Reduviasporonites, suggests the temporary existence of shallow, pond- or lake-like aquatic habitats, possibly related to tectonic activity. J. Micropalaeontol. 32(2): 183-195, July 2013.
\end{abstract}

KEYWORDS: fungal palynomorphs, fungal proliferation, Oligocene/Miocene boundary, Nukhul Formation, Gulf of Suez, Egypt

\section{INTRODUCTION}

There has been growing interest recently in fungal palynomorphs of different ages and areas all over the world (e.g. Lange \& Smith, 1971; Sherwood-Pike \& Gray, 1985; Jarzen \& Elsik, 1986; Ediger \& Alişan, 1989; Kumar, 1990; Srivastava \& Binda, 1991; Takahashi, 1991; Eshet et al., 1995; Visscher et al., 1996; Kalgutkar, 1997; Parsons \& Norris, 1999; Steiner et al., 2003; Vajda \& McLoughlin, 2004; Kalgutkar \& Braman, 2008; Kar et al., 2010; Krings et al., 2010, van Geel et al., 2011; Vajda, 2012). In contrast, no detailed palynological studies on fossil fungi have so far been carried out from Egyptian sediments or other North African and Arabian areas. Such fungal palynomorphs have been noted sporadically from the Tertiary and Cretaceous of this area (e.g. Abdel Mohsen, 1992; Ahmed \& Pocknall, 1994; Mahmoud, 2000; El Beialy et al., 2005; El Atfy, 2011) but without taking into consideration their potential for stratigraphic and palaeoenvironmental interpretations.

The present study is focused on the description of the fungal assemblages and their distribution through the Nukhul Formation in GH 404-2A Well, southern Gulf of Suez, Egypt (Fig. 1). Furthermore, we aim to apply fungal palynomorphs as a palaeoenvironmental indicator and to point out their potential use as a biostratigraphic proxy.

\section{GEOLOGICAL SETTING}

The Gulf of Suez is approximately $300 \mathrm{~km}$ long with an average width of $70 \mathrm{~km}$ and forms the northern extension of the Red Sea, covering an area of about $25000 \mathrm{~km}^{2}$ at an average water depth of 55-100 m (Schlumberger, 1984; Young et al., 2000). It extends to the $\mathrm{NW}$ from $27^{\circ} 30^{\prime} \mathrm{N}$ to $30^{\circ} 00^{\prime} \mathrm{N}$ and its width varies from about $50 \mathrm{~km}$ at its northern end to about $90 \mathrm{~km}$ at its southern end where it merges with the Red Sea (Bosworth \& McClay, 2001). Tectonic subsidence and sedimentation were slow during the initial phase of rifting, which was related to the separation of the African and Arabian plates from the latest Oligocene to the Early Miocene (c. 24-15.5 Ma). The corresponding sedimentary succession shows an upward transition from continental volcanics and red beds of the Abu Zenima Formation to initially terrigenous clastics in fluvial, deltaic and littoral environments followed by marginal marine clastics of the Nukhul Formation (e.g. Scott \& Govean, 1985; Patton et al., 1994). The Gulf of Suez is the main oil-producing province in Egypt, with oil being produced from Palaeozoic, Mesozoic and Cenozoic rocks.

\section{LITHOSTRATIGRAPHY}

The Nukhul Formation was formally described by the Egyptian General Petroleum Corporation Stratigraphic Committee (EGPC, 1964). Its type section is $60 \mathrm{~m}$ thick at the tributary south of Wadi Nukhul, central Sinai coastal Gulf of Suez, Egypt (Fig. 1). In subsurface sections, its thickness varies from $0 \mathrm{~m}$ on structural highs to over $700 \mathrm{~m}$ in the depocentres of the rift sub-basins (Richardson \& Arthur, 1988). The Nukhul Formation is in general poorly dated due to the scarcity of diagnostic foraminifera and nannoplankton (El-Heiny \& Martini, 1981; Evans, 1988), but 


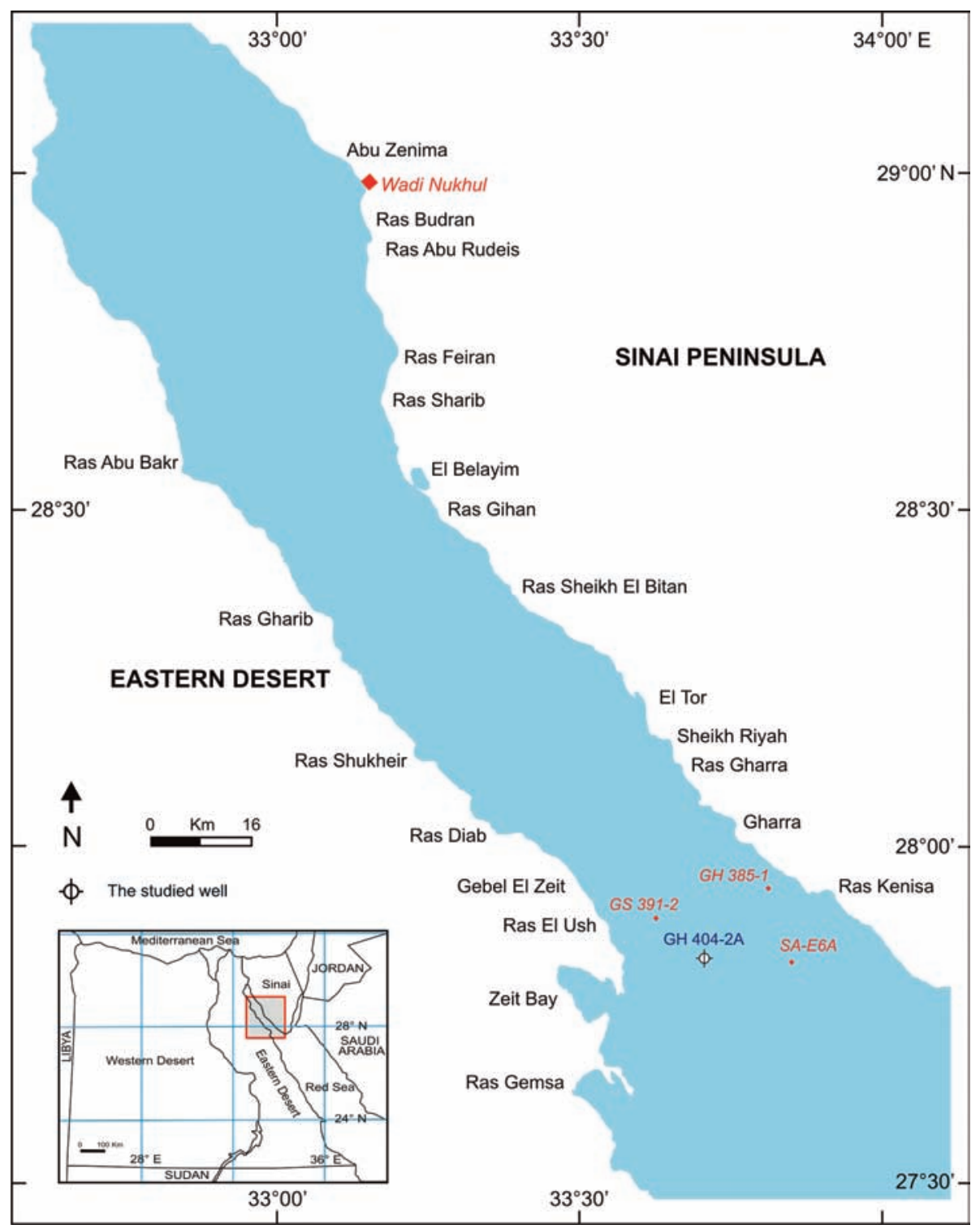

Fig. 1. Location map of the studied well (GH 404-2A), the type section of the Nukhul Formation (Wadi Nukhul) and the type wells of the Shoab Ali and Ghara members, Gulf of Suez, Egypt. Map based mainly on GUPCO (1983).

it has been frequently assigned to the Early Miocene (e.g. Souaya, 1966; Andrawis \& Abdel Malik, 1981; El-Heiny \& Martini, 1981; Evans, 1988; El Heiny \& Morsi, 1992; El-Barkooky et al., 2006; Youssef, 2011) based on foraminifera, calcareous nannofossils and the relative stratigraphic position. Based on palynology (mainly dinocysts), the Nukhul Formation is dated as Early Miocene: Aquitanian and Aquitanian to midBurdigalian (Ahmed \& Pocknall, 1994; Soliman et al., 2012, respectively). Recently, Hewaidy et al. (2012) dated the Nukhul Formation as Late Oligocene-Early Miocene, based on planktonic and benthonic foraminifera from a surface exposure in Sinai. A similar age was postulated by Al-Husseini (2012) from the Gulf of Suez based on a tuned orbital-forcing glacio-eustatic time-scale (Fig. 2). The Nukhul Formation overlies pre-rift basement ranging in age from the Precambrian to Middle-Late
Eocene, depending upon the degree of uplift and erosion prior to Nukhul deposition (Richardson \& Arthur, 1988).

Saoudi \& Khalil (1984) subdivided the Nukhul Formation into two members: the lower Shoab Ali Member with continental clastics which were deposited in the oldest syn-rift graben of the Gulf of Suez, and the upper Ghara Member which is distributed more widely. Due to lateral facies differences, Saoudi \& Khalil (1984) distinguished three regional synonymous members: October Member, Ghara Member and Gharamul Member.

The Shoab Ali Member was originally described from the $\mathrm{GH}$ 385-1 Well (Saoudi \& Khalil, 1984). It is composed predominantly of siliciclastics, mainly sand and sandstone. The sand is generally loose, colourless to pink or yellow, fine- to mediumgrained and is coarser near the bottom. The sandstone is well- to fairly well-sorted, subrounded with streaks of reddish-brown shale 
Fungi near the Oligocene/Miocene boundary, Egypt

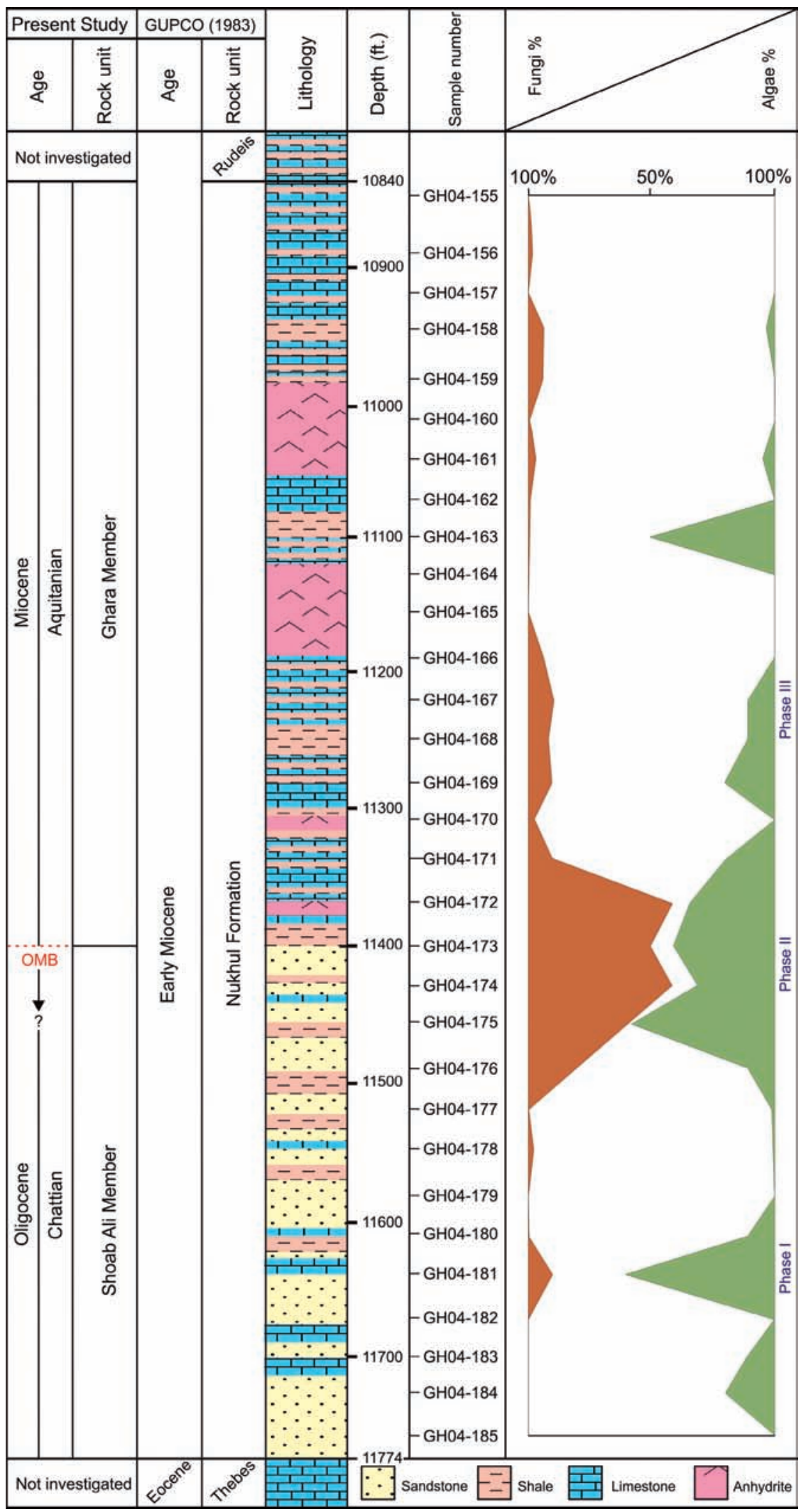

Fig. 2. Lithological log of the Nukhul Formation, GH 404-2A Well, Gulf of Suez, Egypt, modified after GUPCO (1983). The OMB is placed tentatively at the lithological boundary between the Shoab Ali and Ghara members (Hewaidy et al., 2012, and this study). According to sequence stratigraphy, the OMB is somewhere below (Al-Husseini, 2012, as expressed by ? on the figure). The figure also shows the proportional distribution of fungi and algae in three phases. 
and mostly barren of fossils. The Shoab Ali Member unconformably overlies the Thebes Formation.

In the current work, we apply the nomenclature of Saoudi \& Khalil (1984) for the upper member, utilizing the term Ghara Member which geographically and lithologically fits best to our material. The Ghara Member was described originally from the Well GS 391-2 (Saoudi \& Khalil, 1984), approximately $9 \mathrm{~km}$ from our studied well. It is composed mainly of white and hard anhydrite layers interbedded with sandstones, grey marls, calcareous shales and limestones. The Ghara Member follows the Shoab Ali Member conformably and is unconformably overlain by the Rudeis Formation (basal Rudeis Member) or its correlative the Mheiherrat Formation.

The studied interval in the GH 404-2A Well ranges from 10 $840 \mathrm{ft}$ to $11774 \mathrm{ft}$. (934ft thick), comprising both the Shoab Ali Member and the overlying Ghara Member (Fig. 2).

\section{MATERIAL AND METHODS}

Thirty cutting samples retrieved from the Nukhul Formation from the GH 404-2A Well were prepared for palynological analysis following standard extraction techniques; $\mathrm{HCl}-\mathrm{HF}-\mathrm{HCl}$ treatment (e.g. Traverse, 2007), and finally sieving the residues using $10 \mu \mathrm{m}$ nylon sieves. No oxidation methods were employed. The studied portion of the organic residue was stained with Safranin solution and then mounted on slides using ICI's Elvacite acrylic resin. The fungal assemblages were studied routinely under transmitted light microscope, followed by epi-fluorescence investigation to distinguish fungal spores from algae and other spores and pollen (Pl. 3, fig. M). Fungi were described and classified according to the relevant literature (mainly Elsik et al., 1983; Kalgutkar \& Jansonius, 2000) including the world-wide records of stratigraphically diagnostic taxa (e.g. Saxena, 2006; Palynodata Inc. \& White, 2008). Characteristic representatives of the recorded taxa are illustrated on Plates 1-3. They were analysed and documented using a Nikon Eclipse 90i microscope, equipped with an infrared video system (specified in Brocke \& Wilde, 2001) for studying dark-coloured to nearly opaque palynomorphs (e.g. Pl. 2, figs N, O). Specimen locations on the slides are given as England Finder coordinates. The relevant slides and residues are stored in the palynological collection (Section Palynology and Microvertebrates of the Palaeozoic) at the Senckenberg Research Institute and Natural History Museum, Frankfurt am Main, Germany.

\section{RESULTS AND DISCUSSION}

The studied samples yielded moderate to well-preserved fungal and algal palynomorphs, in relatively higher numbers compared to other palynomorphs (dinocysts, spores and pollen), reflecting a considerable fungal and algal proliferation especially within the interval $11370-11430 \mathrm{ft}$, with a lower concentration to 11 $490 \mathrm{ft}$ (Fig. 2).
Most of the investigated samples were poorly fossiliferous and few taxa were recorded. As we are dealing with cuttings, the occurrence and ranges of microfossils within the profile may be partially inconsistent in terms of small-scale stratigraphic accuracy.

The microscopic examination clearly shows that the reported fungal assemblages did not result from a contaminating effect of sample storage as all samples were preserved in a similar way; also, fungal proliferation has been witnessed exclusively in a definite interval (Fig. 2). The melanized red-brown colour of the fungal taxa is also very characteristic of fossilized forms. Furthermore, the primary high hydrocarbon content of the samples may serve as a preservation medium against any biological attack by modern fungi.

The fungal remains (including spores, fructifications and hyphae) are common in the studied samples and they contribute up to $>50 \%$ of the total palynomorph assemblage, especially within the fungi-rich interval (11 370-11 $430 \mathrm{ft}$, Fig. 2). It is also worth mentioning that no definite taxonomic group of fungi dominates - as is clear from the recorded taxa. Representative taxa are grouped and sorted (Fig. 3; Table 1) depending on the number of cells in fungal spores under descriptive headings (monocellate, dicellate and multicellate), fruiting bodies and fungal hyphae, rather than being classified under the system for Fungi Imperfecti of Saccardo (1899).

The presence of this well-developed fungal proliferation follows a clear lithological change from coarse-grained siliciclastics to fine-grained marls, limestones and evaporites at the boundary between the Ghara and Shoab Ali members of the Nukhul Formation. Moreover, freshwater algae, such as Botryococcus and Pediastrum, occur partly synchronous to the fungal proliferation and in relatively similar concentration around this interval.

Also, the investigated material lacks or has very few dinocysts, spores and pollen which could serve for biostratigraphic purposes, but it may be possible to locate the OMB (at least provisionally) at or near the lithostratigraphic boundary between the two members of the Nukhul Formation. This is based on age determinations from spores and pollen in the present well and in SA-E6A Well, which indicate that the upper part of the Shoab Ali Member is Late Oligocene in age (El Atfy et al., in press). The proliferation of the fungi and freshwater algae may serve to correlate between well sections at the postulated OMB (Fig. 2). The fungal palynomorphs also support a terrestrial origin deposited within a regional terminal regressive phase, indicated by the dominance of siliciclastics and, palynologically, by the frequent abundance of phytoclasts (El Atfy et al., in press). Indeed, the fossil fungi are frequently found in both terrestrial and aquatic environments, although the terrestrial group usually appears to be dominant based on their higher diversity and greater relative frequencies

\footnotetext{
Explanation of Plate 1. Fungal palynomorphs from the Nukhul Formation, GH 404-2A Well, Gulf of Suez, Egypt: monocellate fungal spores. fig. A. Exesisporites annulatus; GH04-174-1; EF X35-1. fig. B. Exesisporites neogenicus; GH04-176-1; EF B31-1. fig. C. Inapertisporites sp.; GH04-1741; EF O53-1. fig. D. Inapertisporites sp.; GH04-176-1; EF D48-2. fig. E. Inapertisporites circularis; GH04-172-1; EF D41-1. fig. F. Inapertisporites communis; GH04-174-1; EF P30-2. fig. G. Monoporisporites macrosporus; GH04-172-2; EF J45-2. fig. H. Monoporisporites traversii; GH04-1721; EF J43-4. fig. I. Spirotremesporites cf. clinatus; GH04-176-1; EF G45-3. fig. J. Striadiporites sp.; GH04-172-2; EF P32-4. fig. K. Striadiporites boletelloides; GH04-176-1; EF O47-1. fig. L. Striadiporites bistriatus; GH04-168-2; EF A58-3. fig. M. Striadiporites reticulatus; GH04-174-1; EF M39-4. fig. N. Striadiporites restriatus; GH04-176-1; EF U33-3. fig. O. Striadiporites inflexus; GH04-174-1; EF D53-3. fig. P. Striadiporites spiralis; GH04-174-1; EF E29-2. An England Finder reference (e.g. EF X35-1) follows the sample number (e.g. GH04-174) and slide number (e.g. -1, -2) for each specimen. All images are transmitted light photomicrographs; scale bars $10 \mu \mathrm{m}$.
} 

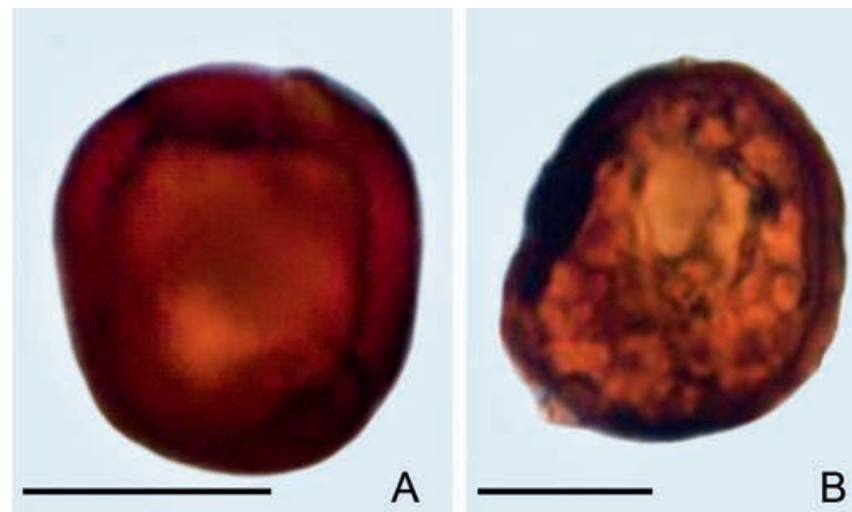

B

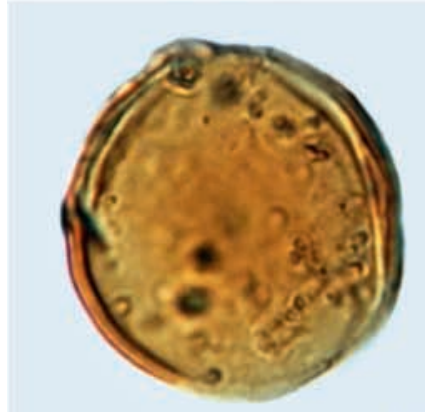

E
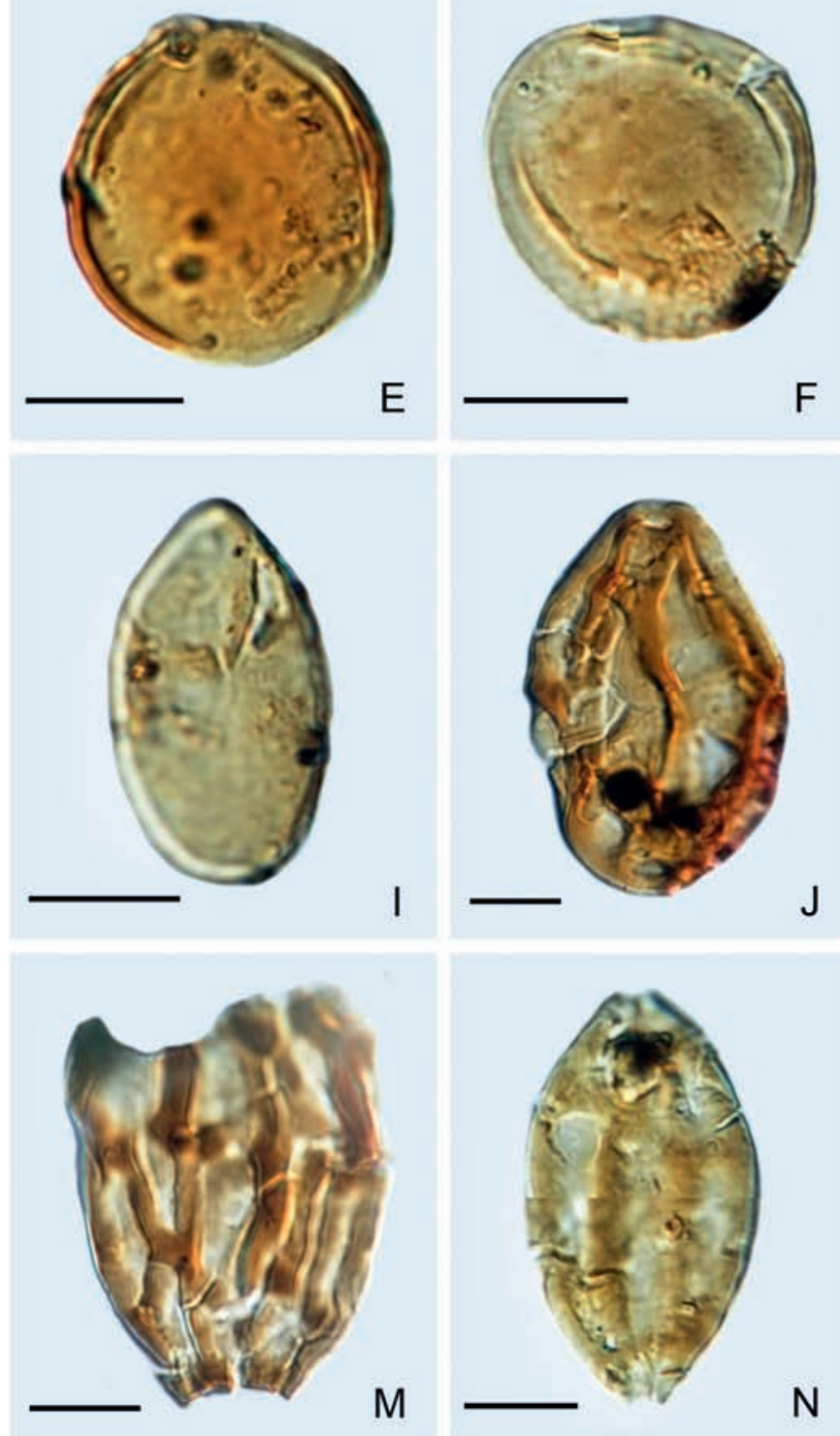
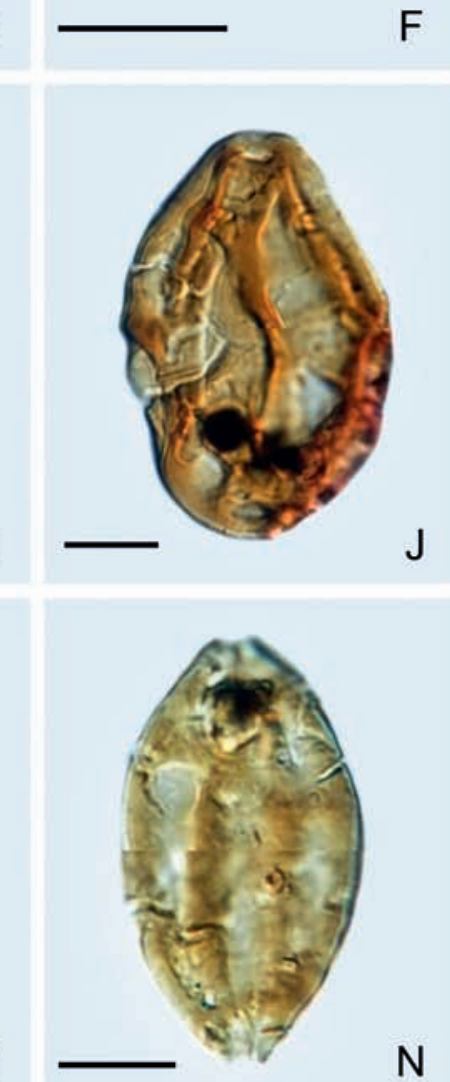
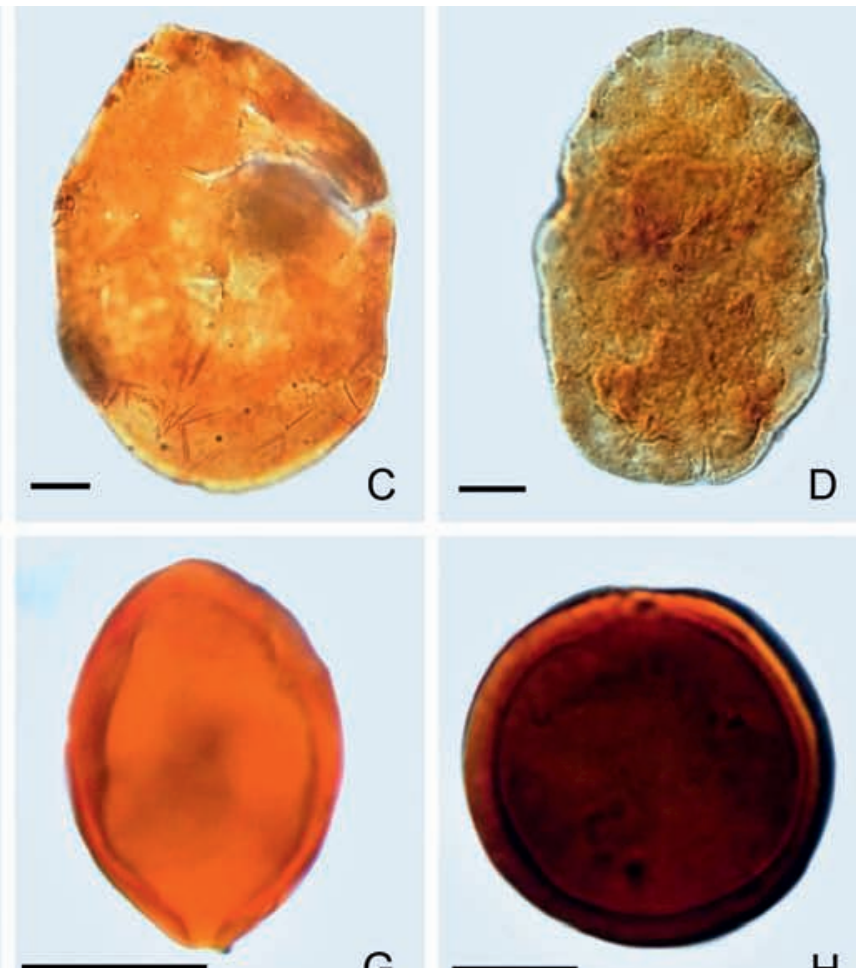

F

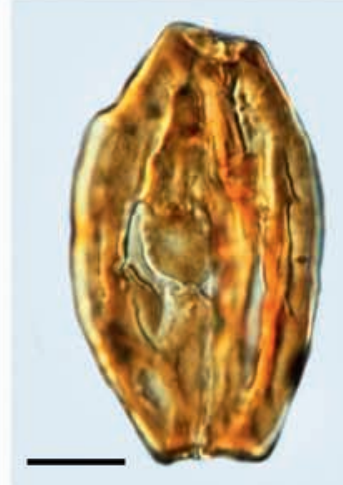

G

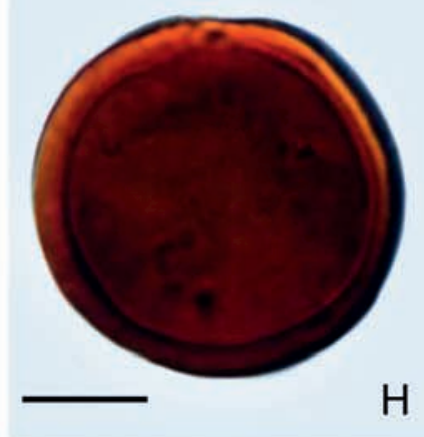

$\mathrm{H}$

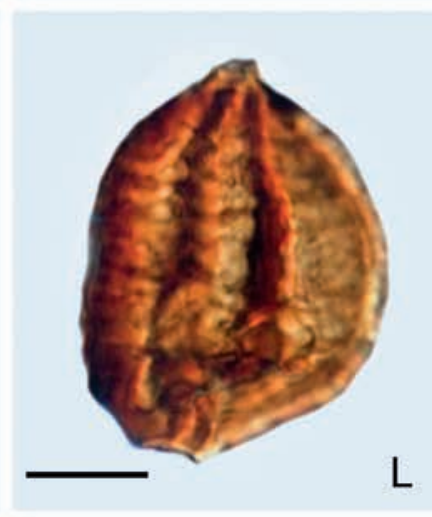

$\mathrm{K}$

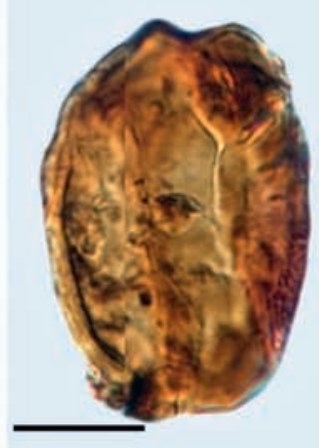

0

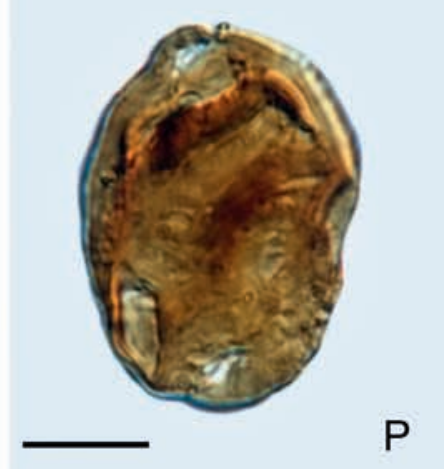




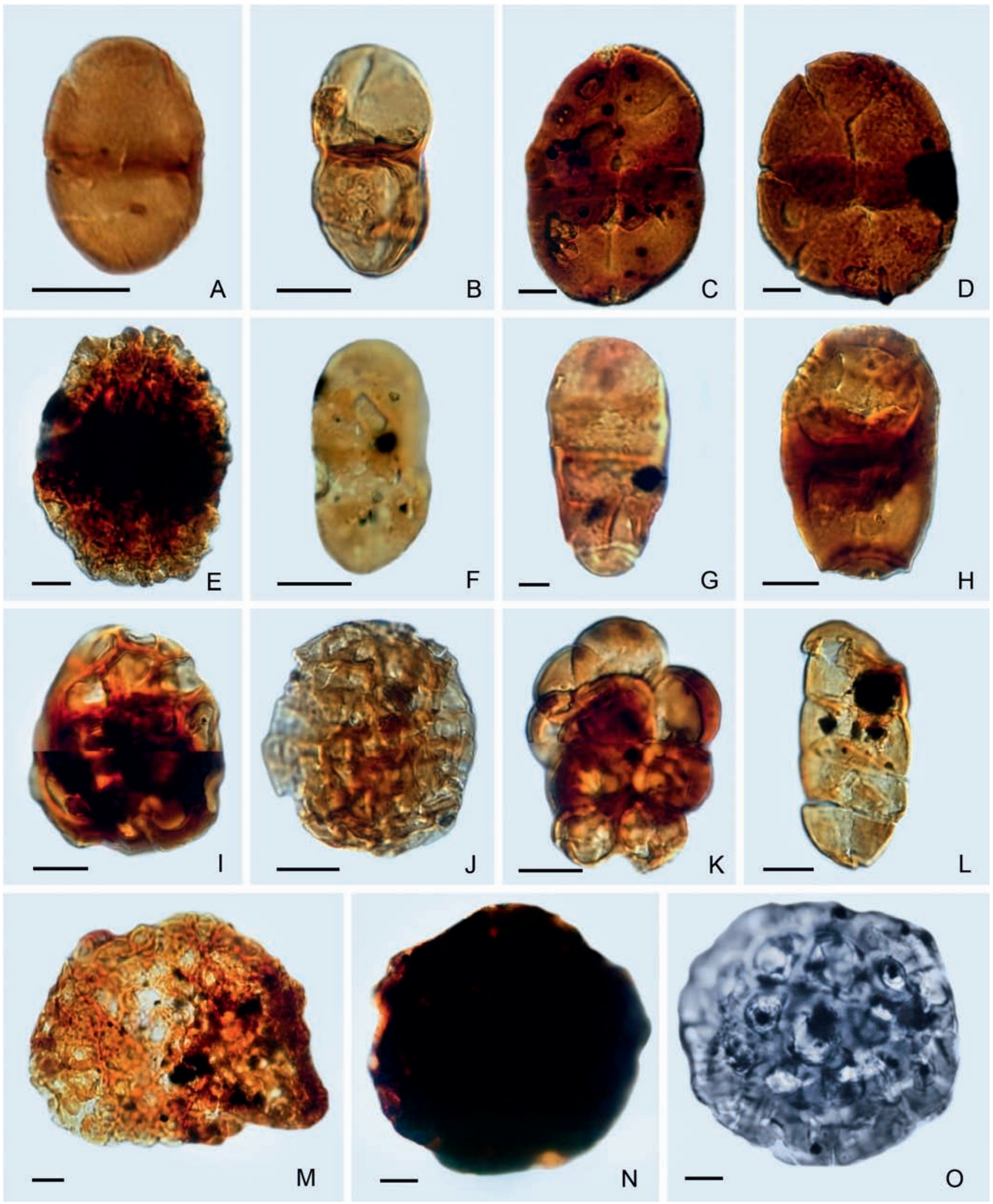


(Kalgutkar \& Braman, 2008). In our assemblages, terrestrial taxa, such as Dicellaesporites, Diporicellaesporites, Multicellites, Scolecosporites and Pluricellaesporites, prevail.

Long-ranging fungal taxa that have been recorded previously from Paleogene as well as Neogene strata include the following genera: Inapertisporites, Lacrimasporonites, Spirotremesporites, Biporopsilonites, Dicellaesporites, Diporicellaesporites, Dyadosporites, Tetraploa/Frasnacritetrus, Involutisporonites, Fusiformisporites, Multicellaesporites, Meliolinites, Pluricellaesporites, Basidiosporites, Staphlosporonites, Dictyosporites, Papulosporonites, Polycellaesporonites, Callimothallus, Phragmothyrites, Stomiopeltites, Trichothyrites, Paragranatisporites, Involutisporonites, Reduviasporonites and Striadiporites.

The recorded fungal assemblages are highly diverse and contain a large proportion of long-ranging taxa. Van der Hammen (1954) was the first to incorporate the relative abundance of fungal palynomorphs in a stratigraphic study and, subsequently, Varma \& Rawat (1963) raised such an application to the species level. The implementation of fungal palynomorphs in biostratigraphy is still not widely used in comparison, for example, with those of the 'standard' foraminifera, calcareous nannofossil or dinocyst biostratigraphies within the Tertiary. However, the growing interest among palaeontologists in fungal remains and knowledge about their geological record is continually improving (Elsik, 1996; Kalgutkar \& Jansonius, 2000; Taylor \& Krings, 2010).

Generally, long-ranging fungal taxa that have been recorded previously from Paleogene as well as Neogene strata at generic level are not useful for stratigraphic consideration. Only some taxa at species level may show good biostratigraphic potential (e.g. Striadiporites spp., Palaeoamphisphaerella pirozynskii, Pls 1-3; Fig. 3). Other forms that have been recorded from Neogene sediments but are absent in the Paleogene are: Quilonia spp., Exesisporites spp. and Brachysporisporites spp. and, as a result, they may have some biostratigraphic significance.

The following discussion summarizes some relevant taxa at the postulated OMB. The genus Striadiporites is an important taxon regarding biostratigraphy and palaeoecology; in our material several specimens can be assigned to this genus. One of them, Striadiporites sp. (P1. 1, fig. J; Fig. 3) is similar to Striadiporites sp. of Elsik (1996). This species was used to distinguish Neogene from Paleogene strata in the Gulf of Mexico and the Pacific Northwest, USA. A morphologically similar specimen was also recorded from the Miocene of India (Banerjee \& Nandi, 1992). S. reticulatus (P1. 1, fig. M; Fig. 3) was first described from India by Varma \& Rawat (1963) as a good stratigraphic marker for the Early Miocene. Moreover, this species was also recorded from the Oligocene-Early Miocene of India (Kalgutkar \& Jansonius, 2000). S. sanctaebarbarae (Fig. 3) was also first reported from India by Varma \& Rawat (1963) and proposed by them as a good stratigraphic marker for the Early Miocene. In Turkey, S. sanctaebarbarae was recorded from the Eocene-Oligocene and Late Miocene (Tortonian-Messinian) (Ediger, 1981; Ediger \& Alişan, 1989; Ediger et al., 1996). Younger records include the MiddleLate Miocene of Clarkia in Idaho (Sherwood-Pike, 1988). However, it was recently also reported from the Paleocene of Pakistan (Soomro et al., 2010). In our samples, taxa of this genus occur mainly just below, at or just above the assumed OMB and thus this genus could be regarded as a good biostratigraphic marker for this interval.

Phragmothyrites concentricus (P1. 3, fig. C; Fig. 3) was originally described from the Early Miocene in north central Idaho by Phipps \& Rember (2004). This species is reported here from the top of the Shoab Ali Member.

Palaeoamphisphaerella pirozynskii (P1. 2, fig. F; Fig. 3) was originally published from the Early Miocene (Ramanujam \& Srisailam, 1980), and it was also reported from the Miocene (Mallesham et al., 1989) of India. In our samples, P. pirozynskii occurs at the top of the Shoab Ali Member and at the base of the Ghara Member (the ?OMB interval).

Exesisporites neogenicus (P1. 1, fig. B; Fig. 3) was first described by Elsik (1969) from the Early Miocene of the Gulf of Mexico, and subsequently recorded from the Middle-Late Eocene (Bera \& Banerjee, 1995) and Early Miocene (Mandaokar, 2002) of India. In our samples E. neogenicus occurs both near the top of the Shoab Ali Member and at the base of the Ghara Member (the ?OMB interval).

Dicellaesporites keralensis (P1. 2, fig. B; Fig. 3) was described originally from Early-Middle Miocene (Kumar, 1990) and subsequently from the Early Eocene (Samant, 2000) of India. This species is reported here from the top of the Shoab Ali Member.

\section{FUNGAL SPIKE}

Fungal spikes in the geological record are well known to co-occur with certain bio-events and have been documented from different geographical localities and time periods (e.g. Eshet et al., 1995; Visscher et al., 1996; Steiner et al., 2003; Vajda \& McLoughlin, 2004). Moreover, fungal spikes are also considered to have the potential to characterize ecostratigraphic or even biostratigraphic boundaries (Parsons \& Norris, 1999). The well-known and widespread fungal proliferation near the Permian-Triassic boundary has frequently been interpreted as widespread devastation of arboreous vegetation, a major decrease in standing biomass and the build-up of decaying vegetation on land (e.g. Visscher \& Brugman, 1986; Visscher et al., 1996, 2011; Steiner et al., 2003). However, to our knowledge this is the first time that a comparable fungal proliferation has been documented in the Tertiary, except only for a record at the Cretaceous-Tertiary boundary from New Zealand (Vajda \& McLoughlin, 2004). This peak was interpreted

Explanation of Plate 2. Fungal palynomorphs from the Nukhul Formation, GH 404-2A Well, Gulf of Suez, Egypt. figs A-F. Dicellate fungal spores: A, Dicellaesporites inaequabilis; GH04-176-1; EF Y52-1; B, Dicellaesporites keralensis; GH04-174-1; EF P30-1; C, Dyadosporites solidus; GH04-170-1; EF X30-2; D, Dyadosporites bhardwaji; GH04-168-1; EF D38-1; E, Dyadosporites cf. reticulatus; GH04-172-1; EF T60-2; F, Palaeoamphisphaerella pirozynskii; GH04-174-1; EF P30-1. figs G-O. Multicellate fungal spores: G, Anatolinites cf. dongyingensis; GH04-162-2; EF H49-2; H, Paragranatisporites cf. vermiculus; GH04-174-1; EF O38-3; I, Dictyosporites moruloides; GH04-181-1; EF N48-4; J, Dictyosporites morularis; GH04-174-1; EF X41-1; K, Involutisporonites sp.; GH04-168-2; EF P63-4; L, Meliolinites cf. nivalis; GH04-181-1; EF W31-1; M, Palambages sp.; GH04-170-1; EF M35-1; N, Papulosporonites enormis; GH04-176-1; EF Y39-3; O, Papulosporonites enormis; GH04-176-1; EF Y393. An England Finder reference (e.g. EF X35-1) follows the sample number (e.g. GH04-174) and slide number (e.g. -1, -2) for each specimen. All images are transmitted light photomicrographs with the exception of fig. $\mathrm{O}$ which is an infrared image; scale bars $10 \mu \mathrm{m}$. 

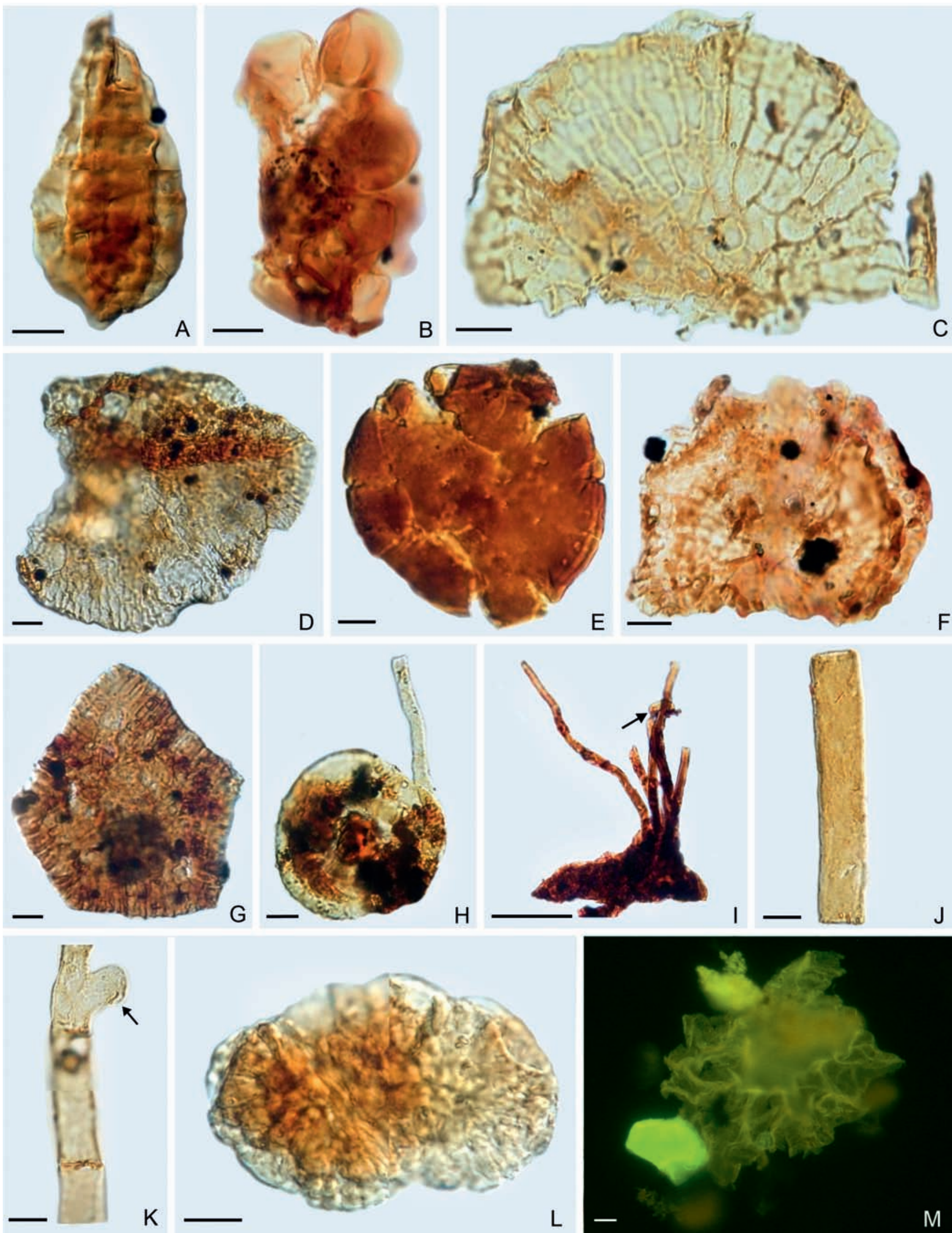

F
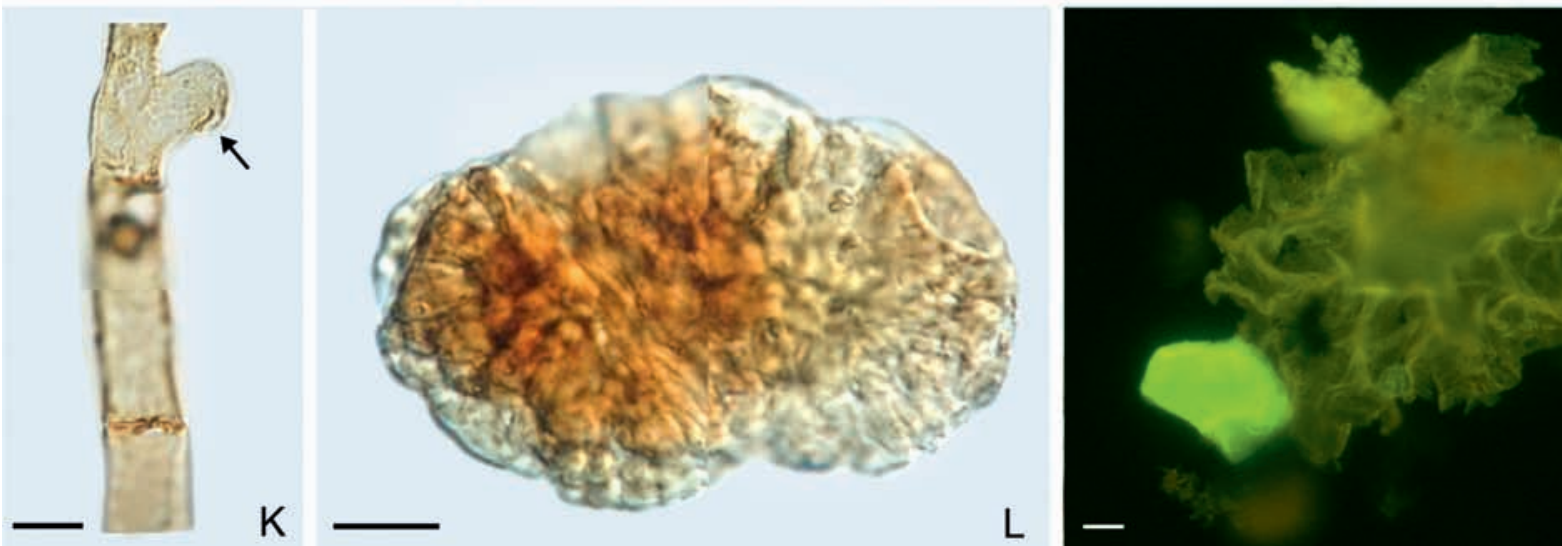

L 
Table 1. List of species and authors from Figure 3.

Anatolinites dongyingensis (Ke \& Shi, 1978) Elsik et al., 1990

Brachysporisporites catinus (Elsik \& Jansonius, 1974) Kalgutkar \& Jansonius, 2000

Dicellaesporites inaequabilis Martínez-Hernández \& Tomasini-Ortiz, 1989 Dicellaesporites keralensis Kumar, 1990

Dictyosporites morularis (Salard-Cheboldaeff \& Locquin, 1980) Kalgutkar \& Jansonius, 2000

Dictyosporites moruloides (Salard-Cheboldaeff \& Locquin, 1980) Kalgutkar \& Jansonius, 2000

Dyadosporites bhardwaji (Varma \& Rawat, 1963) Kalgutkar \& Jansonius, 2000

Dyadosporites reticulatus (Ramanujam \& Rao, 1979) Kalgutkar \& Jansonius, 2000

Dyadosporites solidus (Ke \& Shi, 1978) Song in Song et al., 1999

Exesisporites annulatus Kalgutkar, 1993

Exesisporites neogenicus Elsik, 1969

Inapertisporites circularis (Sheffy \& Dilcher, 1971) Kalgutkar \& Jansonius, 2000

Inapertisporites communis Song \& $\mathrm{Li}$ in Song et al., 1989

Meliolinites nivalis Selkirk, 1975

Monoporisporites macrosporus (Salard-Cheboldaeff \& Locquin, 1980) Kalgutkar \& Jansonius, 2000

Monoporisporites traversii (Ediger \& Alisan, 1989) Kalgutkar \& Jansonius, 2000

Palaeoamphisphaerella pirozynskii Ramanujam \& Srisailam, 1980 Papulosporonites enormis (Ediger, 1981) Kalgutkar \& Jansonius, 2000

Paragranatisporites vermiculus (Ediger, 1981) Kalgutkar \& Jansonius, 2000

Phragmothyrites concentricus Phipps \& Rember, 2004

Polycellaesporonites acuminatus (Rouse \& Mustard, 1997) Kalgutkar \& Jansonius, 2000

Reduviasporonites qingfengensis (Song \& Luo, 1989) Song in Song et al., 1999

Spirotremesporites clinatus Elsik, 1990

Striadiporites bistriatus (Ke \& Shi, 1978) Norris, 1986

Striadiporites boletelloides Salard-Cheboldaeff \& Locquin, 1980

Striadiporites inflexus (Ke \& Shi, 1978) Norris, 1986

Striadiporites reticulatus Varma \& Rawat, 1963

Striadiporites retistriatus (Ke \& Shi, 1978) Kalgutkar \& Jansonius, 2000

Striadiporites sanctaebarbarae Elsik \& Jansonius, 1974

Striadiporites sp. Elsik, 1996

Striadiporites spiralis (Song \& Li, 1989) Kalgutkar \& Jansonius, 2000

to represent a dramatic increase in the available substrates for saprophytic organisms provided by global forest dieback after the Chixculub impact (Vajda et al., 2001).

In the current study, we present the first evidence of a fungal proliferation from sediments deposited at or within an interval close to the supposed OMB of Egypt (Fig. 2). The recorded proliferation appears in three phases, which are composed mainly of fungal spores, fungal fragments, fructifications and hyphae together with freshwater algae. The first (minor) phase is displayed in sample GH04-181 at $11640 \mathrm{ft}$. The second or main phase occurs in the fungi-rich interval between $11370 \mathrm{ft}$ and11 $430 \mathrm{ft}$, which is overlain by a third (minor) phase in sample GH04-167 (11 220 ft). The width of the main peak may be explained partly as a result of blurring due to the use of cutting samples, but it seems highly unlikely that the different individual peaks are the result of such a distortion (Fig. 2). Altogether, these three proliferations document a fungal peak or acme accompanied by a lithological change from siliciclastics to calcareous rocks which we believe probably represents the transition from the Oligocene to the Miocene.

Kar et al. (2010) recorded a comparable high proportion of fungal hyphae, spores and microthyriaceous ascostromata in Early Miocene sediments in India, whereas spores and pollen grains were relatively rare and of low diversity, similar to our material. Hence, at a first glance this record of fungal palynomorphs from a unit in India of comparable age could be interpreted as an indication of an inter-regional eco-event and support the presence of a close relationship in the composition of fungi from different areas in the Early Miocene or around the OMB, respectively. But, indeed, it clearly needs much more information from other areas of the world to establish such an event and to exclude taphonomic effects, in order to compare these findings with, for example, the famous end-Palaeozoic fungal spike at the Permian-Triassic boundary or that at the Cretaceous-Tertiary boundary (e.g. Eshet et al., 1995; Vajda \& McLoughlin, 2004).

\section{PALAEOENVIRONMENTAL INTERPRETATION}

Fossil fungal palynomorphs exhibit a great variability in their morphology and have good potential as indicators for past ecosystems. Their presence in sedimentary sequences provides significant and reliable proxies in understanding the depositional environments as well as to support palaeoclimatic inferences (Pirozynski, 1976; Stubblefield \& Taylor, 1988; Kalgutkar \& Braman, 2008; Singh \& Chauhan, 2008). Recently, there has been a remarkable increase in the application of fossil fungi in both biostratigraphical and palaeoenvironmental studies; in particular, they are known to adapt and respond quickly to environmental stress and disturbance (Pugh \& Boddy, 1988). Furthermore, certain fungal taxa are useful in palaeoenvironmental determinations based mainly on the ecological significance of their extant or modern analogues with well-known environmental preferences, e.g. as principal decomposers of organic matter they are of distinct significance for ecosystem dynamics (e.g. Taylor \& Krings, 2010). In general, a rich diversity of fungal

Explanation of Plate 3. Fungal palynomorphs from the Nukhul Formation, GH 404-2A Well, Gulf of Suez, Egypt. figs A-G. Fungal fruiting bodies: A, Polycellaesporonites acuminatus; GH04-158-1; EF O61-4; B, Reduviasporonites cf. qingfengensis; GH04-168-2;K EF X51-4; C, Phragmothyrites concentricus; GH04-174-1; EF Y50-3; D, Phragmothyrites sp.; GH04-174-1; EF O53-1; E, cf. Stomiopeltites sp.; GH04-181-1; EF S35-1; F, Trichothyrites sp.; GH04-168-2; EF B34-3; G, Trichothyrites sp.; GH04-168-2; EF F40-0. figs H-K. Fungal hyphae: H, Palaeomycites sp.; GH04-176-2; EF Q421; I, GH04-176-3; EF Q40-4; J, non-septate fungal hyphae; GH04-176-1; EF X33-2; K, hyphopodiate fungal hyphae with conspicuous septations and hyphopodia at the arrow; GH04-174-1; EF U43-4. figs L, M. Freshwater algae: L, Botryococcus sp.; GH04-172-2; EF V48-2; M. Pediastrum sp.; GH04172-1; EF K40-4. An England Finder reference (e.g. EF X35-1) follows the sample number (e.g. GH04-174) and slide number (e.g. -1, -2) for each specimen. All images are transmitted light photomicrographs with the exception of fig. M which is a fluorescence image; scale bars $10 \mu \mathrm{m}$. 


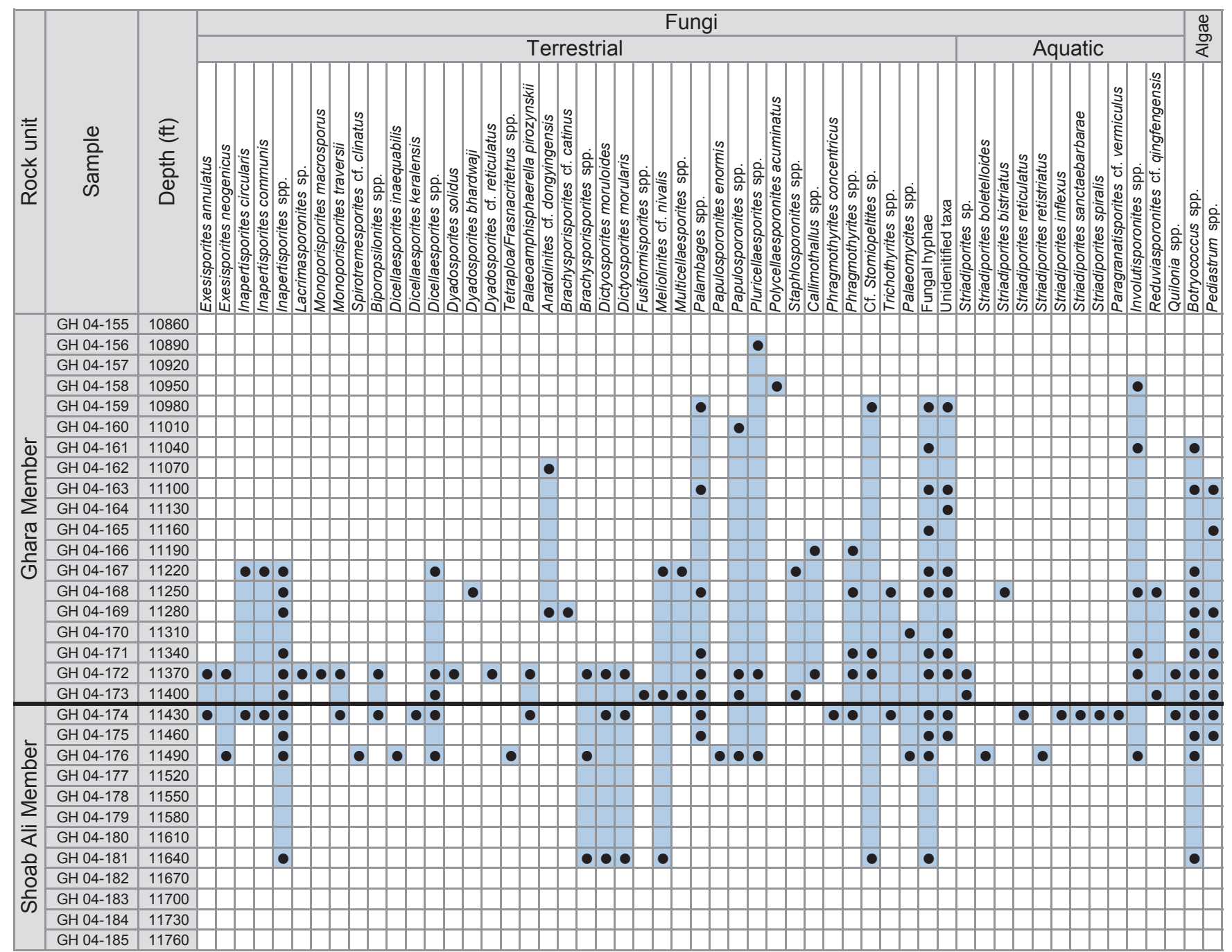

Fig. 3. Distribution pattern of recorded fungal and algal microfossils in the studied well interval.

remains is interpreted as an indication of the prevalence of a humid climate in the area of deposition (Singh \& Chauhan, 2008). In addition, changes in diversity and relative abundance of fungal palynomorphs can reflect palaeoclimatic as well as other palaeoenvironmental changes/fluctuations (Elsik, 1996; Kloosterboer-van Hoeve et al., 2006).

The genera Tetraploa/Frasnacritetrus (in sample GH04-176 only) and Exesisporites were considered as grassland fungi, and the latter have been interpreted as indicators of a warm climate for Pliocene deposits of the northern Gulf of Mexico (Elsik, 1969; Antoine et al., 2006). Common occurrences of Exesisporites and Staphlosporonites could provide evidence for a swamp environment close to the sea with periodical freshwater flooding; this in agreement with an earlier assumption of Parsons \& Norris (1999).

Taxa such as Dicellaesporites, Diporicellaesporites, Multicellites, Scolecosporites, and Pluricellaesporites are commonly attributed to saprophytes beneath the forest canopy when optimum conditions of moisture and temperature existed (Kalgutkar \& Braman, 2008).

The presence of helicoid fungal spores is generally related to brackish and/or marine conditions as deduced from modern dema- tiaceous hyphomycete taxa, such as Cirrenalia (Kalgutkar \& Braman, 2008; Abdel-Wahab et al., 2010). Also, Ingold (1942) observed that most of the water fungi live luxuriantly in the running water, whereas aeroaquatic or helicosporous aquatic hyphomycetes occur predominantly in stagnant freshwater, sometimes also under marine conditions. Moreover, it has been assumed that they also indicate tropical, humid climatic conditions prevailing during the sedimentation of the Miocene Quilon Beds of India (Kumar, 1990). Involutisporonites was interpreted to represent aquatic environments with open, marshy and waterlogged areas (Kalgutkar, 1993).

The co-occurrence of Botryococcus and Pediastrum (the latter in lower concentration), with few specimens of aquatic fungal genera, such as Involutisporonites, Paragrantisporites, Quilonia, Striadiporites and Reduviasporonites, suggests the existence of shallow, pond-like aquatic habitats, comparable to a previously noted environment from the Milk River Formation in Canada by Braman (2002). Moreover, such co-occurrence was used by Mudie et al. (2002) as a marker of terrigenous sediment influx and transport by river runoff during the Holocene of the 
Black Sea. Although we are aware of the ongoing discussion concerning whether Reduviasporonites represents fungi or algae, we follow here the 'classical' interpretation as fungal remains, as recently supported by Visscher et al. (2011). In addition, a routine fluorescence investigation has been employed to ensure chitinous rather than an algal origin for all reported taxa including Reduviasporonites.

The existence of isolated ascocarps of epiphyllous microthyriaceous fungi, such as Phragmothyrites (P1. 3, figs C-D), Trichothyrites and Callimothallus, also supports the assumption of a warm and humid climate during the deposition of the Nukhul Formation (mainly within the defined ?OMB interval), similar to the interpretation for the Milk River Formation (Kalgutkar \& Braman, 2008). The same is true for the presence of epiphyllous microthyriaceous fruiting bodies that are generally taken as a reliable indicator of warm temperate to tropical climatic conditions (Lange, 1976; Kalgutkar \& Braman, 2008). The co-occurence of Meliola/Meliolinites ( $\mathrm{Pl}$. 2, fig. L) with epiphyllous fungi is also indicative for high humidity coupled with high temperature (Dilcher, 1963; Singh \& Chauhan, 2008).

Due to the scarcity of outcrop information, limited palaeontological data and intense tectonics, it is difficult to establish a definite depositional regime for the Nukhul Formation; however, a rather complex depositional scenario can be envisioned (cf. El Atfy et al., 2013). For example, Carr et al. (2003) postulated two contemporaneous environments for the deposition of the Nukhul Formation: (1) an open-shelf offshore to shoreface environment; and (2) a structurally controlled estuary. Both the recorded fungal palynomorphs and freshwater algae, in addition to the overall sparse and rare record of marine dinocysts, support the depositional model of a structurally controlled estuary or freshwater to brackish lake. In addition, it has been mentioned previously by Lorente (1986) that an absence of marine microplankton, a dominance of fungal remains and an abundance of the local flora are usually characteristics of coastal plain deposition including that of estuaries. Autochthonous fungal remains occur abundantly in moist-wet environments, e.g. river-bank deposits (Jarzen \& Elsik, 1986), lake-beds (Wolf, 1966) and inter-tidal marginal marine environments (Hughes, 1968; Lorente, 1986; Srivastava \& Binda, 1991).

Fungi thrive not only during such climatic-controlled humid conditions, but always in wetlands (and other) ecosystems, e.g. peat swamps, and may expand during the humid conditions (cf. Kloosterboer-van Hoeve et al., 2006), probably located at the margin of a large body of water. It is possible that such peat deposits (not directly recorded in our material) may have been eroded and/or reworked during the initial phase of the transgression which is evidenced by the clear lithological change from sandstones to shales around $11400 \mathrm{ft}$, marking the top of the Shoab Ali Member.

As our main observed fungal proliferation is most likely situated close to or at the OMB, it may be possible that the lowstand (top Shoab Ali Member) prior to the observed transgression (basal Ghara Member) may be related to the Mi-1 glaciation event of Miller et al. (1991), which resulted in eustatic sea-level changes (regression during glaciation, transgression during deglaciation). This glaciation represents the first occurrence of a fullscale ice-sheet on Antarctica (Zachos et al., 2001) and its effects on sea-level fall and probably global climate changes have been reported previously from localities as far north as Denmark
(Larsson et al., 2010; and citations therein). The presence of more than one fungal/algal peak probably represents the results of different transgressive pulses of varying magnitude.

Indeed, due to extensive tectonic movements during the deposition of the Oligocene-Miocene sediments of the entire Gulf of Suez basin, it seems likely that the regression/transgression processes, which have led to the assumed erosion of sediments enriched in fungal remains, may have been caused or overprinted by more local or regional tectonic movements and not only due to glacio-eustatic sea-level changes or taphonomic considerations.

\section{CONCLUSIONS}

The palynological examination of 30 samples from the Nukhul Formation of the GH 404-2A Well, Gulf of Suez, Egypt, revealed the presence of a prominent proliferation of fungal and algal palynomorphs which 'peaked' at the boundary between the Shoab Ali and Ghara members within the Nukhul Formation. The fungal proliferation, which is recorded in the present study for the first time, may probably represent an eco-event at or near the assumed OMB in the Gulf of Suez. Species, such as Exesisporites neogenicus, Palaeoamphisphaerella pirozynskii, Striadiporites sp., are considered here as potentially stratigraphically diagnostic to characterize the OMB interval.

The presence of such a fungal proliferation is most likely an indication of humid and warm climatic conditions beginning at the turning point from a regressive to a transgressive phase. It probably took place through several small pulses of transgression during the terminal lowstand. The presence of three phases of fungal and algal proliferation could be an indicator of such a process. The succeeding calcareous lithology of the Ghara Member is progressively characterized by evaporites which are interpreted to reflect arid conditions. This may have led to increased erosion and contemporaneous redeposition.

Moreover, co-occurrence of freshwater algae, such as Pediastrum and Botryococcus, with some aquatic fungal genera, such as Involutisporonites, Paragrantisporites, Quilonia, Striadiporites and Reduviasporonites, suggests the existence of shallow, lake/ pond-like or lacustrine aquatic habitats, probably related to the rifting activities or sea-level rise during the initial transgressive phase. This phase is characterized by erosion and probably due to ongoing transgression(s), subsequent erosion and accumulation.

\section{ACKNOWLEDGEMENTS}

The German Academic Exchange Service (DAAD) is gratefully acknowledged for supporting the first author in his research at the Senckenberg Research Institute, Frankfurt am Main, Germany (grant A/10/92695). Part financial support from the Biodiversität und Klimaforschungszentrum Frankfurt (BiK-F) is also acknowledged. We thank Prof. Dr. Dr. h.c. Volker Mosbrugger for his continuous support. The authors are grateful to the Egyptian General Petroleum Corporation (EGPC) and the Gulf of Suez Petroleum Company (GUPCO) for the provision of samples and well logs. The authors are grateful to the Handling Editor and an anonymous reviewer for their constructive comments. This study was conducted as a part of the $\mathrm{PhD}$ research project of $\mathrm{H}$. El Atfy.

Manuscript received 5 February 2013

Manuscript accepted 24 April 2013

Scientific Editing by Martin Pearce 


\section{REFERENCES}

Abdel Mohsen, S.A. 1992. Cretaceous plant microfossils from the subsurface of Kharga Oasis, Western Desert, Egypt. Journal of African Earth Sciences, 14: 567-577.

Abdel-Wahab, M.A., Pang, K.L., Nagahama, T., Abdel-Aziz, F.A. \& Gareth Jones, E.B. 2010. Phylogenetic evaluation of anamorphic species of Cirrenalia and Cumulospora with the description of eight new genera and four new species. Mycological Progress, 9: 537-558.

Ahmed, A.B.A. \& Pocknall, D.T. 1994. The application of palynology to exploration in the Miocene-Pliocene sequence in the Gulf of Suez, Egypt. In Proceedings of 12th Petroleum Exploration and Production Conference, Egyptian General Petroleum Corporation, EGPC, Cairo, 468-481.

Al-Husseini, M. 2012. Late Oligocene-Early Miocene Nukhul Sequence, Gulf of Suez and Red Sea. GeoArabia, 17(1): 17-44.

Andrawis, S.F. \& Abdel Malik, W.M. 1981. Lower Miocene boundary in the Gulf of Suez region, Egypt. Newsletters on Stratigraphy, 10: 156-163.

Antoine, P., Franceschi, D., Flynn, J.J. et al . 2006. Amber from western Amazonia reveals Neotropical diversity during the middle Miocene. Proceedings of the National Academy of Sciences of the USA, 103: 13 595-13 600.

Banerjee, S. \& Nandi, B. 1992. Fossil fungi from Miocene sediments of Mizoram and their environmental significance. Journal of Mycopathological Research, 30: 81-88.

Bera, S. \& Banerjee, M. 1995. Eocene palynoassemblage from lignite deposits of West Bengal, India with remarks on environment of deposition. Indian Journal of Earth Science, 22: 149-152.

Bosworth, W. \& McClay, K.R. 2001. Structural and stratigraphic evolution of the Gulf of Suez rift, Egypt: A synthesis. In Zeigler, P.A., Cavazza, W., Robertson, A.H.F. \& Crasquin-Soleau, S. (Eds), Peri-Tethys. Memoir 6 : Peri-Tethyan Rift/Wrench Basins and Passive Margins. Memoires du Museum National d'Historie Naturelle de Paris, 186: 567-606.

Braman, D.R. 2002. Terrestrial palynomorphs of the upper Santonian?lowest Campanian Milk River Formation, Southern Alberta, Canada. Palynology, 25: 57-107.

Brocke, R. \& Wilde, V. 2001. Infrared video microscopy - an efficient method for the routine investigation of opaque organic-walled microfossils. Facies, 45: 157-164.

Carr, I.D., Gawthorpe, R.L., Jackson, C.A.L., Sharp, I.R. \& Sadek, A. 2003. Sedimentology and sequence stratigraphy of early syn-rift tidal sediments: The Nukhul Formation, Suez Rift, Egypt. Journal of Sedimentary Research, 73: 407-421.

Dilcher, D.L. 1963. Eocene epiphyllous fungi. Science, 142: 667-669.

Ediger, V. 1981. Fossil fungal and algal bodies from Tharce Basin Turkey. Palaeontographica, B179: 87-102.

Ediger, V.Ş \& Alişan, C. 1989. Tertiary fungal and algal palynomorph biostratigraphy of the Northern Thrace Basin, Turkey. Review of Palaeobotany and Palynology, 58: 139-161.

Ediger, V.Ş, Bati, Z. \& Kozlu, H. 1996. Tortonian-Messinian palynomorphs from the easternmost Mediterranean region around Iskenderun, Turkey. Micropaleontology, 42: 189-205.

EGPC, Egyptian General Petroleum Corporation Stratigraphic Committee. 1964. Oligocene and Miocene rock stratigraphy of the Gulf of Suez Region. M.A., Ghorab et al (Eds), Egyptian General Petroleum Corporation, Consultative Stratigraphic Committee, Cairo, 142pp.

El Atfy, H. 2011. Cretaceous palynology of the GPTSW-7 Well, Western Desert, Egypt. MSc Thesis, Mansoura University, Egypt. LAP Lambert Academic Publishing, Saarbrücken, Germany, 137pp.

El Atfy, H., Brocke, R. \& Uhl, D. in press. Age and paleoenvironment of the Nukhul Formation, Gulf of Suez, Egypt: Insights from palynology, palynofacies and organic geochemistry. GeoArabia.

El-Barkooky, A.N., El-Araby, A. \& Gaupp, R. 2006. Early syn-rift deposition of alluvial-lacustrine facies in Wadi Nukhul, west central Sinai, Egypt. Egyptian Journal of Geology, 50: 141-169.

El Beialy, S.Y., Mahmoud, M.S. \& Ali, A.S. 2005. Insights on the age, climate and depositional environments of the Rudeis and Kareem
Formations, GS-78-1 Well, Gulf of Suez, Egypt: A palynological Approach. Revista Española de Micropaleontología, 37: 273-289.

El-Heiny, I. \& Martini, E. 1981. Miocene foraminiferal and calcareous nanno-plankton assemblages from the Gulf of Suez region and correlation. Géologie Méditerranee, 8: 101-108.

El Heiny, I. \& Morsi, S. 1992. Stratigraphic correlation of Neogene sediments in the eastern Nile Delta and Gulf of Suez, Egypt. In Proceedings of 11th Petroleum Exploration and Production Conference, Egyptian General Petroleum Corporation, EGPC, Cairo, 166-193.

Elsik, W.C. 1969. Late Neogene palynomorph diagrams, northern Gulf of Mexico. Gulf Coast Association of Geological Societies Transactions, 19: 509-528.

Elsik, W.C. 1996. Fungi. In Jansonius, J. \& McGregor, D.C. (Eds), Palynology: principles and applications, 1: 293-305.AASP Foundation, Dallas.

Elsik, W.C., Baesmann, C.B., Graham, A.K. et al. 1983. Annotated glossary of fungal palynomorphs. AASP Contributions Series, 11: 35pp.

Eshet, Y., Rampino, M.R. \& Visscher, H. 1995. Fungal event and palynological record of ecological crisis and recovery across the PermianTriassic boundary. Geology, 23: 967-970.

Evans, A.L. 1988. Neogene tectonic and stratigraphic events in the Gulf of Suez rift area, Egypt. Tectonophysics, 153: 235-247.

GUPCO. 1983. Composite well log and location map of GH 404-2A Well. Gulf of Suez Petroleum Company, Egypt.

Hewaidy, A.A., Farouk, S. \& Ayyad, H.M. 2012. Nukhul Formation in Wadi Baba, southwest Sinai Peninsula, Egypt. GeoArabia, 17(1): 103-120.

Hughes, G.C. 1968. Intertidal lignicolous fungi from Newfoundland. Canadian Journal of Botany, 46: 1409-1417.

Ingold, C.T. 1942. Aquatic hyphomycetes of decaying Alder leaves. Transactions of the British Mycological Society, 25: 339-417.

Jarzen, D.M. \& Elsik, W.C. 1986. Fungal palynomorphs recovered from Recent deposits, Luangwa Valley, Zambia. Palynology, 10: 35-60.

Kalgutkar, R.M. 1993. Paleogene fungal palynomorphs from Bonnet Plume Formation, Yukon Territory. In Reynolds, L. (Ed.), Contributions to Canadian paleontology. Geological Survey of Canada Bulletin, 444: 51-105.

Kalgutkar, R.M. 1997. Fossil fungi from the lower Tertiary Iceberg Bay Formation, Eukeka Sound Group, Axel Heiberg Island, Northwest Territories, Canada. Review of Palaeobotany and Palynology, 97: 197-226.

Kalgutkar, R.M. \& Braman, D.R. 2008. Santonian to ?Earliest Campanian (Late Cretaceous) fungi from the Milk River Formation, Southern Alberta, Canada. Palynology, 32: 39-61.

Kalgutkar, R.M. \& Jansonius, J. 2000. Synopsis of fossil fungal spores, mycelia and fructifications. AASP Contributions Series, 39: 423pp.

Kar, R., Mandaokar, B.D. \& Kar, R.K. 2010. Fungal taxa from the Miocene sediments of Mizoram, northeast India. Review of Palaeobotany and Palynology, 158: 240-249.

Kloosterboer-Van Hoeve, M.L., Steenbrink, J., Visscher, H. \& Brinkhuis, H. 2006. Millennial-scale climatic cycles in the Early Pliocene pollen record of Ptolemais, northern Greece. Palaeogeography, Palaeoclimatology, Palaeoecology, 229: 321-334.

Krings, M., Dotzler, N., Longcore, J.E. \& Taylor, T.N. 2010. An unusual microfungus in a fungal spore from the Lower Devonian Rhynie chert. Palaeontology, 53: 753-759.

Kumar, P. 1990. Fungal remains from the Miocene Quilon Beds of Kerala State, South India. Review of Palaeobotany and Palynology, 62: 13-28.

Lange, R.T. 1976. Fossil epiphyllous 'germlings', their living equivalents and their palaeohabitat indicator value. Neues Jahrbuch für Geologie und Paläontologie Abhandlung, 151: 142-165.

Lange, R.T. \& Smith, P.H. 1971. The Maslin Bay flora, South Australia 3. Dispersed fungal spores. Neues Jahrbuch für Geologie und Paläontologie Monatschefte, 10: 663-681.

Larsson, L.M., Vajda, V. \& Dybkjær, K. 2010. Vegetation and climate in the latest Oligocene-earliest Miocene in Jylland, Denmark. Review of Palaeobotany and Palynology, 159: 166-176.

Lorente, M.A. 1986. Palynology and palynofacies of the Upper Tertiary in Venezuela. Dissertationes Botanicae. Lubrecht and Cramer Ltd, BerlinStuttgart, 222pp. 
Mahmoud, M.S. 2000. Plio-Pleistocene palynology (freshwater algae, spores and pollen) and palaeoecology of the shallow subsurface section, West Assiut, Egypt. Acta Universitatis Carolinae, 44: 101-114.

Mallesham, C., Ramakrishna, H. \& Ramanujam, C.G.K. 1989. Fungal assemblage from the subsurface Miocene sediments of East Coast of southern India. In Proceedings of the Fifth All India Symposium on Palynology, Nagpur, 1979, 15-18.

Mandaokar, B.D. 2002. Palynoflora from the Keifang Formation (Early Miocene), Mizoram, India and its environmental significance. Journal of the Palaeontological Society of India, 47: 77-83.

Miller, K.G., Wright, J.D. \& Fairbanks, R.G. 1991. Unlocking the icehouse: Oligocene-Miocene oxygen isotopes, eustacy, and margin erosion. Journal of Geophysical Research, 96: 6829-6848.

Mudie, P.J., Rochon, A., Aksu, A.E. \& Gillespie, H. 2002. Dinoflagellate cysts, freshwater algae and fungal spores as salinity indicators in Late Quaternary cores from Marmara and Black seas. Marine Geology, 190: 203-231.

Palynodata Inc. \& White, J.M. 2008. Palynodata Datafile: 2006 version, with Introduction by White, J.M. Geological Survey of Canada. Open File, 5793, 1 CD-ROM.

Parsons, M.G. \& Norris, G. 1999. Paleogene fungi from the Caribou Hills, Mackenzie Delta, northern Canada. Palaeontographica, B250: 77-167.

Patton, T.L., Moustafa, A.R., Nelson, R.A. \& Abdine, S.A. 1994. Tectonic evolution and structural setting of the Suez Rift. In S.M., Landon (Ed.), Interior Rift Basins. American Association of Petroleum Geologists Memoir, 59: 7-55.

Phipps, C.J. \& Rember, W.C. 2004. Epiphyllous fungi from the Miocene of Clarkia, Idaho: reproductive structures. Review of Palaeobotany and Palynology, 129: 67-79.

Pirozynski, K.A. 1976. Fossil fungi. Annual Review of Phytopathology, 14: $237-246$.

Pugh, G.J.F. \& Boddy, L. 1988. A view of disturbance and life strategies in fungi. Proceedings of the Royal Society of Edinburgh, 94B: 3-11.

Ramanujam, C.G.K. \& Srisailam, K. 1980. Fossil fungal spores from the Neogene Beds around Cannanore in Kerala state. Botanique, 9: 119-138.

Richardson, M. \& Arthur, M.A. 1988. The Gulf of Suez-northern Red Sea Neogene rift: A quantitative basin analysis. Marine and Petroleum Geology, 5: 247-270.

Saccardo, P.A. 1899. Sylloge fungorum omnium hucusque cognitorum, 1. Pavia, Italy, 1316pp.

Samant, B. 2000. Fungal remains from the Bhavnagar lignite, Gujarat, India. Geophytology, 28: 11-18.

Saoudi, A. \& Khalil, B. 1984. Distribution and hydrocarbon potential of Nukhul sediments in the Gulf of Suez. In Proceedings of 7th Petroleum Exploration and Production Conference, Egyptian General Petroleum Corporation, EGPC, Cairo, 75-96.

Saxena, R.K. 2006. A catalogue of Tertiary fungi from India. Diamond Jubilee Special Publication. Birbal Sahni Institute of Palaeobotany, Lucknow, 37pp.

Schlumberger 1984. Well Evaluation Conference Egypt. Schlumberger Middle East SA, 201 pp.

Scott, R.W. \& Govean, F.M. 1985. Early depositional history of a rift basin: Miocene in Western Sinai. Palaeogeography, Palaeoclimatology, Palaeoecology, 52: 143-158.

Sherwood-Pike, M.A. 1988. Freshwater fungi: Fossil record and paleoecological potential. Palaeogeography, Palaeoclimatology, Palaeoecology, 62: 271-285.

Sherwood-Pike, M.A. \& Gray, J. 1985. Silurian fungal remains: Probable records of the class Ascomycetes. Lethaia, 18: 1-20.

Singh, S.K. \& Chauhan, M.S. 2008. Fungal remains from the Neogene sediments of Mahuadanr Valley, Latehar District, Jharkhand, India and their palaeoclimatic significance. Journal of the Palaeontological Society of India, 53: 73-81.
Soliman, A., Ćorić, S., Head, M.J., Piller, W.E. \& El Beialy, S.Y. 2012. Lower and Middle Miocene biostratigraphy, Gulf of Suez, Egypt based on dinoflagellate cysts and calcareous nannofossils. Palynology, 36: 38-79.

Soomro, S., Leghari, S.M., Lashari, R., Rajar, A.W. \& Abbasi, Q.D. 2010. Fossil fungal spores from brown coal of Sonda, District Thatta, Sindh, Pakistan. Sindh University Research Journal. Scientific Series, 42: 73-84.

Souaya, F.J. 1966. Miocene foraminifera of the Gulf of Suez region, U.A.R. Part 3. Biostratigraphy. Micropaleontology, 12: 183-202.

Srivastava, S.K. \& Binda, P.L. 1991. Depositional history of the Early Eocene Shumaysi Formation, Saudi Arabia. Palynology, 15: 47-61.

Steiner, M.B., Eshet, Y., Rampino, M.R. \& Schwindt, D.M. 2003. Fungal abundance spike and the Permian-Triassic boundary in the Karoo Supergroup (South Africa). Palaeogeography, Palaeoclimatology, Palaeoecology, 194: 405-414.

Stubblefield, S.P. \& Taylor, T.N. 1988. Tansley Review No. 12, Recent advances in palaeomycology. New Phytologist, 108: 3-25.

Takahashi, K. 1991. Fungal and algal palynomorphs from the Tokotan and Kiritappu Formation of the Nemuro Group, eastern Hokkaido. Japanese Journal of Palynology, 37: 151-168.

Taylor, T.N. \& Krings, M. 2010. Paleomycology: The rediscovery of the obvious. Palaios, 25: 283-286.

Traverse, A. 2007. Paleopalynology ( $2^{\text {nd }}$ edn). Springer, Dordrecht, The Netherlands, $813 \mathrm{pp}$.

Vajda, V. 2012. Fungi, a driving force in normalization of the terrestrial carbon cycle following the end-Cretaceous extinction. In J.A., Talent (Ed.), Earth and life, global biodiversity, extinction intervals and biogeographic perturbations through time. Springer, Dordrecht, The Netherlands, pp. 811-817.

Vajda, V. \& McLoughlin, S. 2004. Fungal proliferation at the CretaceousTertiary boundary. Science, 303: 1489.

Vajda, V., Raine, J.I. \& Hollis, C.J. 2001. Indication of global deforestation at the Cretaceous-Tertiary boundary by New Zealand fern spike. Science, 294: 1700-1702.

Van Der Hammen, T. 1954. El desarrollo de la flora colombiana en los períodos geológicos. I: Maestrichtiano hasta Terciario más inferior. (Una investigación palinológica de la formación de Guaduas y equivalentes). Boletín Geológico, II: 49-106.

Van Geel, B., Gelorini, V., Lyaruu, A. et al. 2011. Diversity and ecology of tropical African fungal spores from a 25,000-year palaeoenvironmental record in southeastern Kenya. Review of Palaeobotany and Palynology, 164: 174-190.

Varma, C.P. \& Rawat, M.S. 1963. A note on some diporate grains recovered from Tertiary horizons of India and their potential marker value. Grana Palynologica, 4: 130-139.

Visscher, H. \& Brugman, W.A. 1986. The Permian-Triassic boundary in the Southern Alps: A palynological approach. Memorie Della Societa Geologica Italiana, 34: 121-128.

Visscher, H., Brinkhuis, H., Dilcher, D.L. et al. 1996. The terminal Paleozoic fungal event: Evidence of terrestrial ecosystem destabilization and collapse. Proceedings of the National Academy of Sciences of the USA, 93: 2155-2158.

Visscher, H., Sephton, M.A. \& Looy, C.V. 2011. Fungal virulence at the time of the end-Permian biosphere crisis? Geology, 39: 883-886.

Wolf, F.A. 1966. Fungus spores in east African lake sediments. Bulletin of the Torrey Botanical Club, 93: 104-113.

Young, M.J., Gawthorpe, R.L. \& Sharp, I.R. 2000. Sedimentology and sequence stratigraphy of a transfer zone coarse-grained delta, Miocene Suez Rift, Egypt. Sedimentology, 47: 1081-1104.

Youssef, A. 2011. Early-Middle Miocene Suez Syn-rift-basin, Egypt: A sequence stratigraphy framework. GeoArabia, 16 (1): 113-134.

Zachos, J., Pagani, M., Sloan, L., Thomas, E. \& Billups, K. 2001. Trends, rhythms, and aberrations in global climate $65 \mathrm{Ma}$ to present. Science, 292: 686-693. 


\section{New and Recent Tectonics Titles}
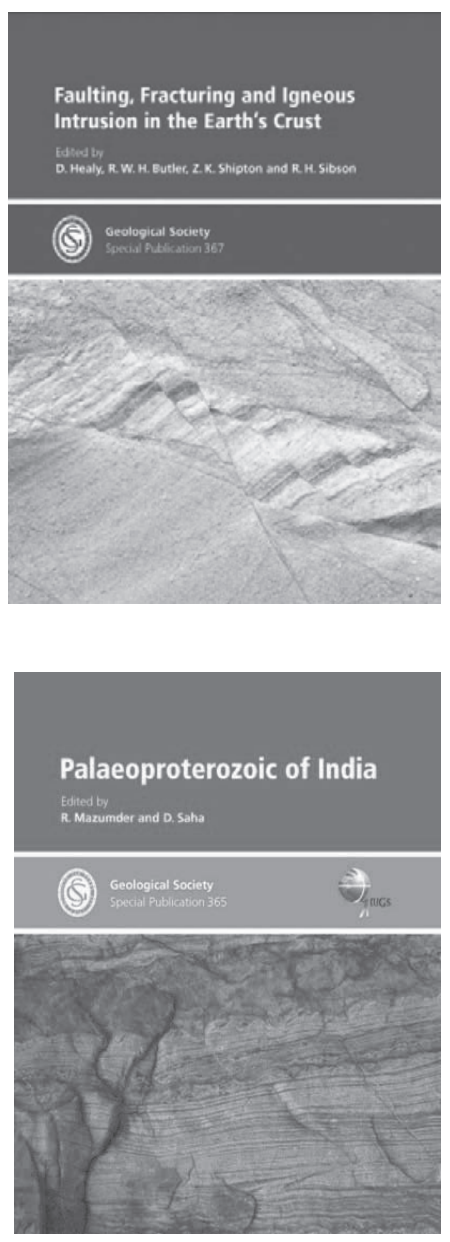

\section{Faulting, Fracturing and Igneous Intrusion in the Earth's Crust}

\author{
Edited by D Healy, R W H Butler, Z K Shipton and R H Sibson
}

This volume celebrates the pioneering research and concepts of Ernest Masson Anderson with 14 original research papers that examine faulting and seismic hazard; structural inheritance; the role of local and regional stress fields; low angle faults and the role of pore fluids; supplemented by reviews of Andersonian approaches and a reprint of his classic paper of 1905.

ISBN: 978-1-86239-347-9 | Hardback | 264 pages | Publication Date: 04 September 2012

List price: $£ 85.00$ Fellow's price: $£ 42.50$ Other societies price: $£ 51.00$

Online Bookshop Code: SP367

\section{Palaeoproterozoic of India}

\section{Edited by R Mazumder and D Saha}

This book covers various aspects of regional geology as well as broader issues of the Indian Palaeoproterozoic geology and its global context. It is an outcome of the UNESCO-IGCP 509 Palaeoproterozoic Supercontinents and Global Evolution research project.

ISBN: 978-1-86239-345-5 | Hardback | 290 pages | Publication Date: 16 April 2012 List price: $£ 95.00$ Fellow's price: $£ 47.50$ Other societies price: $£ 57.00$

Online Bookshop Code: SP365

\section{RECENT}

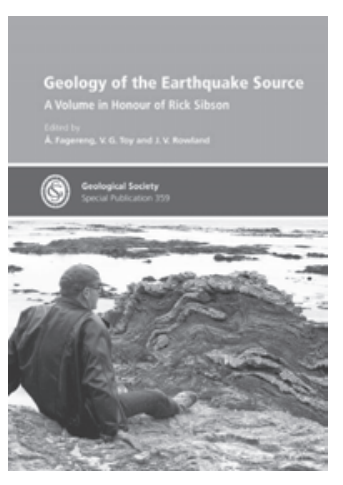

196

\section{Geology of the Earthquake Source:} A Volume in Honour of Rick Sibson Edited by A Fagereng, V Toy and J V Rowland ISBN: 978-1-86239-337-0 22 December 2011 | 341 pages | Hardback

List price: $£ 110.00$ Fellow's price: $£ 55.00$ Other societies price: $£ 66.00$ Online Bookshop code: SP359

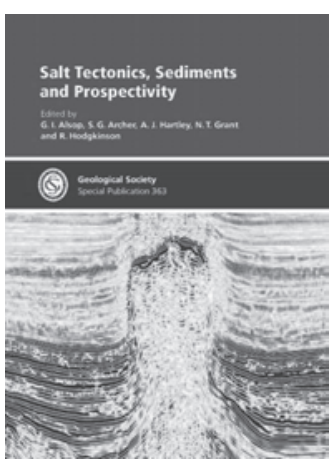

Salt Tectonics, Sediments and Prospectivity Edited by G I Alsop, S Archer, A J Hartley, N Grant and R Hodgkinson ISBN: 978-1-86239-341-7 21 March 2012 | 632 pages | Hardback

List price: $£ 120.00$

Fellow's price: $£ 60.00$

Other societies price: $£ 72.00$

Online Bookshop code: SP363
Order books from:

WWw.geolsoc.org.uk/bookshop

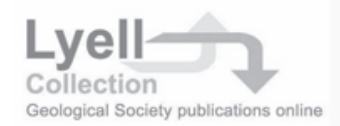

The Geological Society's Lyell Collection: journals, Special Publications and books online. For more information visit www.geolsoc.org.uk/LyellCollection 